\author{
Katarina Marjanovič, Christina Manouilidou and Tatjana Marvin \\ Univerza v Ljubljani, University of Patras, Univerza v Ljubljani
}

\title{
Word-Formation Rules in Slovenian Agentive Deverbal Nominalization: A Psycholinguistic Study Based on Pseudo-Words
}

\begin{abstract}
In this paper we investigate the status of various word-formation rules relating to the derivation of the agentive deverbal nominalization in Slovenian by examining the speakers' perception of pseudo-words that violate these rules. The experiment, based on Manouilidou's (2007) investigation of Modern Greek, includes 20 native speakers of Slovenian. The results show that, contrary to Greek speakers, native speakers of Slovenian make a clear line between pseudowords that violate word-formation rules of Slovenian and words that do not, but that they do not differentiate between pseudo-words with different types of violations, equally rejecting all pseudo words with violations.
\end{abstract}

V članku se ukvarjamo z raziskavo pomena različnih besedotvornih pravil v povezavi z izpeljavo slovenskih samostalnikov, ki označujejo vršilca dejanja, tako da ugotavljamo, kako govorci sprejemajo psevdobesede, ki ta različna besedotvorna pravila kršijo. Poskus temelji na podobnem poskusu za moderno grščino v Manouilidou (2007) in vključuje 20 rojenih govorcev slovenščine. Rezultati pokažejo, da rojeni govorci slovenščine postavijo jasno mejo med psevdobesedami z besedotvornimi kršitvami in obstoječimi slovenskimi besedami (ter psevdobesedami brez kršitev), saj v nasprotju z rojenimi govorci grščine v enaki meri zavračajo vse besede s kršitvami, kar kaže na to, da vsem testiranim besedotvornim kršitvam pripisujejo enak pomen.

\section{Introduction}

The goal of this research is to investigate the status of various word-formation rules in deverbal agentive nominalization in Slovenian by examining speakers' perception of pseudo-words that violate these rules. The study is based on a similar study conducted for Modern Greek in Manouilidou (2007), which showed that native speakers of Modern Greek differentiate among word-formation rules in the sense that some rules are more readily violated than others. Our goal was to establish whether native speakers of Slovenian show a similar behavior, testing the word-formation rules that were tested in Modern Greek, as well as an additional word-formation rule, the status of which had yet to be established. 
The paper is organized as follows. In section 2 we present some general background on word formation in general and on word formation in Slovenian specifically. In section 3 we introduce the notion of a pseudo-word and introduce the types of pseudo-words that we created for the experiment. In section 4 we present the design of the experiment and the results together with a discussion of the results. Section 5 concludes the paper and is followed by an Appendix, where all the stimuli used in the experiment are listed.

\section{Word Formation: Theoretical Background}

Morphology is defined as the area of grammar that is concerned with the structure of words and the relationships among their constituent parts. There are several competing morphological theories, which can roughly be classified as subscribing to either a derivational or to a non-derivational view of grammar; see Spencer (1991), Bauer (2003) and Embick (2010) among others for discussions of various morphological theories. In this paper we do not commit to any particular theory but, rather, adopt a view that draws on insights from various research traditions, as for example the one taken up in O'Grady, Dobrovolsky and Aronoff (1997), or Plag (2003).

In this view, the word is divided into morphemes, minimal linguistic units with a lexical or grammatical meaning. Morphemes can be root morphemes (teach in teacher) or non-root morphemes (-er in teacher). Root morphemes constitute the core of the word and carry the major component of its meaning; they typically belong to a lexical category (usually noun $(\mathrm{N})$, verb $(\mathrm{V})$, adjective $(\mathrm{A})$ ) and are often free, i.e., they can stand on their own (e.g., as bird, teach in English). ${ }^{1}$ Non-root morphemes or affixes (Af), on the other hand, are necessarily bound to the root with which they form a complex word (-ness in politeness, en- in enlarge). The element to which an affix is added is called the base, which in many cases coincides with the root (e.g., institution), but not necessarily (e.g., institution-al). The word-formation process that forms a word with a meaning distinct from that of its base through the addition of an affix is called derivation (teach-er, en-large, polite-ness). ${ }^{2}$ Words can be represented in tree diagrams such as (1) below:

${ }^{1}$ The "general" view we use in this paper presupposes that roots are stored in the lexicon with the information on their category and is thus lexicalist in nature. We adopt such a view because it is the simplest one for expository reasons and not because we would like to argue in favor of it, the issue of root categories not being part of our investigation. For a non-lexicalist view (such as Distributed Morphology), the reader is referred to, e.g., Halle and Marantz (1993), Marantz (2001) and subsequent work.

${ }^{2}$ Morphology is traditionally divided into derivation, which forms new words, and inflection, which forms new forms of a word, encoding grammatical categories such as plural (cups), person (works), tense (worked), case (Johns'). In this paper we only investigate the process of derivation. 
(1) a.

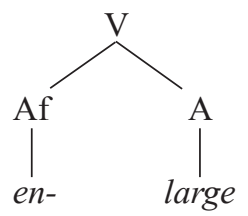

b.

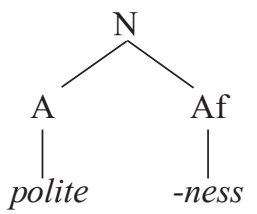

The word-formation process of derivation is limited by different word-formation rules - not all affixes can be attached to all bases (for rules of English affixation see e.g., Fabb (1988), Plag (1996, 1999, 2003), Giegerich (1999)). A common type are the so-called categorial rules, which are word-formation rules relating to the lexical category of the base required for a particular affix; e.g., the suffix -able can only attach to a verbal base, such as drink to derive drinkable, but not to a noun base, such as car to derive * carable. Another type are the so-called thematic rules, which involve word-formation rules about relationships concerning thematic roles; e.g., in agentive nominalization the suffix -er can attach to a verbal root of a verb in which the subject is the agent, e.g., reader, but not to verbs in which the subject is the patient, as, e.g., in * dier. ${ }^{3}$ If these rules are violated, words are built that sound like phonotactically possible words of a certain language but are non-existent due to their violations (*arable, *dier).

\subsection{Word Formation in Slovenian}

In Slovenian, words are composed of morphemes and can be simple, i.e., composed of one morpheme (e.g., le 'only') or complex, i.e., composed of at least two morphemes (e.g., mladost 'youth' $\leftarrow$ mlad- (root) + -ost (suffix) $+\varnothing$ (case ending)). There are different types of word-formation processes in Slovenian, the most common being derivation (mlad $+o s t \rightarrow$ mladost 'youth') and compounding, which is a word-formation process, where two bases are combined to form a new word (e.g., zemlj $+e^{+}$

${ }^{3}$ As to the literature on Slovenian, traditional grammars such as Toporišič (2000) are mostly focused on the rules concerning the category of the base, providing lists of affixes with information on which category of words they derive as well as which category of bases they can be attached to. For English thematic constraints in agentive formation with -er, the reader is referred to Rappaport and Levin (1992), Barker (1998), Marantz (2001) and Alexiadou and Schäfer (2008), among others. 
pis $\rightarrow$ zemljepis 'geography'). ${ }^{4,5}$ Other, less common and less productive word-formation types in Slovenian include juxtaposition (e.g., se ve, da $\rightarrow$ seveda 'of course', 'certainly'), truncation (e.g., gledališc $\breve{s}$ š $\rightarrow$ gledališki 'theatrical'), zero derivation (e.g., dežurni učenec $\rightarrow$ dežurni 'student on duty'), and blends based on orthography - acronyms (e.g., teritorialna obramba 'territorial defense' $\rightarrow T O$ ).

In this section we only provide a brief summary of the main word-formation processes in Slovenian. ${ }^{6}$ In our experiment we focus on only one type - derivation, more specifically on the derivation of nouns with the suffix -ec that denote a masculine agent and are derived from verbal bases (e.g., bralec 'reader'), the so-called agentive (deverbal) nominalization. This nominalization was chosen for several reasons. The affix $-e c$ is one of the most common suffixes in derivation (Stamljič Breznik $(1994 / 95,1999))$ and the nominalization process that derives the masculine agent in $-e c$ is productive, relatively well-studied (Stamljič Breznik (1994/95, 1999), Toporišič (2000), Marvin (2002)), and constrained by clear word-formation rules (see section 3.1.). Also, an analogue nominalization in Modern Greek is studied in Manouilidou's (2007) research, providing an opportunity of a direct comparison.

\section{Pseudo-Words and Possible Words}

The term pseudo-word (sometimes also referred to as jabberwocky stimuli) refers to word formations which resemble regular words of a certain language, but nevertheless have no meaning and are not lexicalized. An example of an English pseudoword is *blunk, a word that does not exist in English despite the fact that it could potentially be part of English vocabulary given that it does not violate any English phonotactic rules. ${ }^{7}$ Pseudo-words such as *blunk can be subject to further derivation, either respecting or violating word-formation rules in the language. For example, from *blunk we can derive the pseudo-word * reblunkable, in which the added affixes impose the lexical category on the pseudo-word *blunk-adding the prefix re-forces *blunk to become a verb and when -able is added to the pseudo-word *reblunk, the word-formation rules for English are respected, as -able attaches to verbs to form

\footnotetext{
${ }^{4}$ In traditional Slovenian linguistics there exists the word-formation type named "ordinary derivation by prefixation" (Toporišič 2000) which is a subtype of the classical derivation. In this type, according to Toporišič's definition, one element of the word base is replaced with a prefix (e.g., zelo star-prastar "very old", višji škof-nadškof"archbishop"). For our purposes, ordinary derivation by prefixation can be subsumed under the term derivation.

${ }^{5}$ The interfix - $e$ - is an affix with the help of which we connect the two combined bases.

${ }^{6}$ For details on traditional Slovenian word-formation processes and types, which only slightly differ from our general description of word-formation types, the reader is referred to Toporišič (2000). Other works that can be consulted for a more thorough investigation of word formation include Stramljič Breznik (1994/95, 1999) and Vidovič Muha (2012).

${ }^{7}$ In this paper, the asterisk is used to indicate a pseudo-word status of a particular combination.
} 
adjectives. The structure of the pseudo-word * reblunkable can be represented in a tree diagram as in (2):

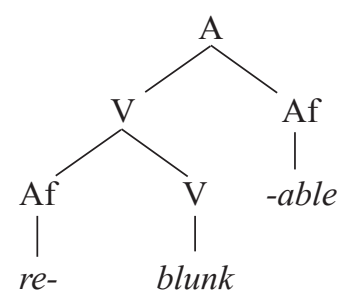

On the other hand, if we attach the affix -ity to the pseudo-verb * reblunk, the result is an ungrammatical pseudo- word * reblunkity since the rules of English word formation allow the suffix -ity to attach to adjectives but not to verbs.

Possible pseudo-words does not only contain words based on non-existing roots such as *blunk, but also words derived from existing roots, which can then either violate or respect word-formation rules of their language. For example, *recarable is a pseudo-word in English, the parts of which are all existing morphemes in English (re-, car, -able), but it is not a possible word in English because it violates English word-formation rules - neither the prefix re-nor the affix -able attach to noun roots such as car. On the other hand, if the same word processes are used on an existing verb root, the word is a possible word of English, e.g., reclickable 'that can be clicked again'.

Both types of pseudo-words described above appear in our experiment. We test a list of words that are phonotactically acceptable in Slovenian yet do not exist because their roots do not exist in the language (termed non-words in our paper, e.g., *dovina). In addition, we test lists of words that are derived from existing roots and either respect Slovenian word-formation rules (pseudo-words that are possible words of Slovenian but are blocked by already existing words derived in a different manner, e.g., *risalec intended meaning: 'draw-er') or do not respect Slovenian word-formation rules (pseudo-words with various types of violations, e.g., *viselec intended meaning: 'hang-er', preplavalec intended meaning: 'swim-pf-er', *črkilec intended meaning: 'letter-er'). ${ }^{8}$ See section 3.1. for an explanation and for further examples.

${ }^{8}$ The English glosses of pseudo agentive nominalizations in Slovenian are provided in the form 'verb-er', where 'verb' in the English glosses corresponds to the Slovenian verbal base, while the affix '-er' is the English equivalent of the Slovenian affix -ec. Such glosses are used regardless of whether the actual nominalization in -er exists in English and whether (if it exists) it carries the meaning 'one who is the agent of the event denoted by the verb'. Also, spelling conventions are ignored in cases where the final vowel is lost in spelling or where the final consonant is doubled in existing English equivalents (e.g., 'admire-er' and 'run-er' are used as glosses for admirer, runner). The existing (i.e., non-pseudo) agentive nominalizations are translated with their English equivalent (e.g., plavalec 'swimmer'). 


\subsection{The Present Study: Materials}

In our experiment we focus on various violations of word-formation rules, creating lists of pseudo-words containing different types of violations and asking native speakers of Slovenian to provide their acceptability judgments. We limit ourselves to the derivation of Slovenian deverbal nouns involving the suffix -ec, whose meaning is 'a masculine agent of the event denoted by the root verb'. Similarly to the research based on Modern Greek, Manouilidou (2007), we consider thematic (3.1.1) and categorial (3.1.2) violations. We add yet another type of violation, not found in Manouilidou's research, so-called aspectual violations (3.1.3) as well as deverbal nous denoting an agent in $-e c$ that do not violate any word-formation rule but are, nevertheless, nonexistent in Slovenian due to the existence of another word with the same meaning, so-called possible pseudo-words (3.1.4). The last group of pseudo-words contains so-called non-words, words that sound like words of Slovenian, but are not found in the language (3.1.5). Our morphological analysis of agentive nominalization relies on the analysis found in Marvin (2002).

\subsubsection{Pseudo-Words with Thematic Violations}

Slovenian deverbal nouns with the suffix $-e c$ can only be derived from verbs in which the subject is the agent of the action described by the verb, as pointed out in Marvin (2002). Therefore, intransitive verbs, in which the syntactic argument of the verb is not a semantic agent of the verb, cannot be found in such nominalizations, as illustrated in (3).

(3) a. *umiralec 'die-er'

b. *viselec 'hang-er'

The same is true of verbs, in which the syntactic argument of the verb is an experiencer rather than agent:

(4) a. *ljubilec 'love-er'

b. *trpelec 'suffer-er'

\subsubsection{Pseudo-Words with Categorial Violations}

Slovenian deverbal nouns with the suffix $-e c$ can only be derived from a base that includes a verbal root. If we derive these nominalizations out of a base that includes a nominal root, such as črk- 'letter' and vaz- 'vase' in (5), the results are ungrammatical forms.

(5) a. *črkilec 'letter-er'

b. *vazilec 'vase-er' 
Here, we would like to point out the difference between the morphological analysis in Marvin (2002), which we adopt for the purpose of creating our pseudo-words, and that in Toporišič (2000). The two differ in stating to what constituent the suffix $-e c$ attaches in this type of agentive nominalization. According to Toporišič (2000), there are several suffixes with the same function of creating agentive nouns (-alec, $-e l e c$, -ilec and -ec) which can be attached to verbal roots, e.g., plav + alec 'swimmer', or mor + ilec, 'murderer', whereas, according to Marvin (2002), there is just a single suffix with the same function, namely $-e c$, which is attached to the verbal base, which in this analysis is not only a verbal root, but an l-participle (e.g., plaval + ec 'swimmer', or moril +ec 'murderer'). ${ }^{9}$

While the difference may not be of great importance when deriving nouns from verbal bases, it is important when deriving nouns from (presumably) noun bases. When we created pseudo-words with categorial violations, where instead of basing the agentive nominalizations on a verb root we based them on noun roots, we actually did not add the suffix $-e c$ directly to the nominal root, but rather to the pseudo$l$-participle derived from a nominal root, such as črkil- or vazil- in (5).This way we followed the analogy with the existing derived agentive nouns, where the productive pattern is attaching -ec to the verbal base in the form of an $l$-participle of the verbal root and not attaching $-e c$ to the root, a pattern that is much more rarely found in the language. ${ }^{10}$

\subsubsection{Pseudo words with aspectual violations}

Aspectual properties of the base also have to be taken into consideration in Slovenian agentive noun formation with -ec. Such nouns can only be derived from the imperfective forms, such as, e.g., plavati 'to swim-imp' (plavalec 'swimmer') and moriti 'to murder-imp' (morilec 'murderer'), but not from the perfective forms preplavati 'to swim-pf' and umoriti 'to murder-pf', as observed in Marvin (2002) and illustrated in (6). In our experiment, we thus created a list of words containing what we term aspectual violations:

(6) a. *preplavalec (from preplavati 'to swim-pf')

b. *umorilec (from umoriti 'to murder-pf')

${ }^{9}$ The main argument for such treatment is the fact that in the vast majority of such nominalizations, the base vowel in Toporišič's -alec, -ilec and -elec overlaps with the thematic vowel of the root verb that appears also in the $l$-participle. The reader is referred to Marvin (2002) for details of this analysis.

${ }^{10}$ When creating this type of pseudo-words, we decided to take the verbal base with the vowel $-i$ - as a default form. 


\subsubsection{Possible Pseudo-Words}

In our experiment we created yet a fourth type of pseudo-words, consisting of words that do not violate any word-formation rule of Slovenian, but nevertheless do not exist in Slovenian vocabulary since there are other lexicalized forms conveying the meaning of a masculine agent in the language. For example, the word * risalec could be a word for 'draw-er' as it does not violate any categorial, thematic or aspectual rules, however, it is not found in the language because it is blocked by the word risar 'drawer'. ${ }^{11}$

(7) a. *risalec 'draw-er' (existing word: risar 'drawer')

b. *kuhalec 'cook-er' (existing word: kuhar 'cook')

\subsubsection{Non-Words}

The last group of pseudo-words created for the purpose of our experiment contains so-called non-words. These are words which do not break phonotactic rules of Slovenian and sound as if they belonged to Slovenian vocabulary but do not exist in the language and do not carry any meaning because their roots have not been lexicalized:

(8) *dovina, *lastje

\section{The experiment}

The main goal of our research was to find out whether native speakers of Slovenian differentiate between pseudo-words which violate different word-formation rules (i.e., pseudo-words with thematic, categorial, and aspectual violations) and whether they make a distinction between these pseudo-words and pseudo-words that do not violate any word-formation rules (i.e., possible pseudo-words). We approached these questions by creating an acceptability task which was presented to 20 young native speakers of Slovenian.

\subsection{Hypotheses}

Based on the findings of a previous study for Modern Greek (Manouilidou 2007) which dealt with the processing of pseudo-words by speakers of Modern Greek, we expected a difference in the acceptance rates for pseudo-words with different types of violations. Higher acceptance rates were expected for pseudo-words with

${ }^{11}$ The term blocking, used in our naming of this kind of pseudo-words, refers to a linguistic situations in which existence of one form (in our case of a lexicalized word of Slovenian, e.g., kuhar), prevents the existence of another form, which would be otherwise expected, Embick (2007). 
thematic violations (e.g., *viselec) than for pseudo-words with categorial violations (e.g., * ${ }^{*}$ rkilec). ${ }^{12}$ As for pseudo-words with aspectual violations (e.g., *preplavalec), we were interested in finding out if the acceptance rates for this category were similar to the acceptance rates of pseudo-words with thematic violations or of pseudo-words with categorial violations, but we did not have any expectations one way or the other since this kind of category was not previously included in the research done for Modern Greek. For the last group, words we termed possible pseudo-words, higher acceptance rates than for other three types of pseudo-words were expected since these pseudo-words do not violate any word-formation rule of the Slovenian language but, nevertheless, do not exist in Slovenian vocabulary since there is another word lexicalized and in use to describe the particular masculine agent. The hypotheses can be briefly summarized as in (9):

(9) Hypothesis 1: Higher acceptance rates for pseudo-words with thematic violations than for pseudo-words with categorial violations;

Hypothesis 2: Higher acceptance rates for possible pseudo-words than for pseudo-words with thematic, categorial or aspectual violations.

\subsection{Methodology}

In order to test the above hypotheses and to find the answers to our research questions, we created an acceptability task in which we presented stimuli belonging to six different categories. The participants were 20 young Slovenians, selected by stratified sampling from the population of 18 to 40 years of age (M age: 27.3), 11 of them were men and 9 women, all of them had 13 or more years of education ( $M$ years of education: 16.3). The stimulus set included 172 stimuli: 22 pseudo-words with thematic violations (e.g., *viselec), 30 pseudo-words with categorial violations (e.g., * crkilec), 30 pseudo-words with aspectual violations (e.g., *preplavalec), 30 possible pseudo-words (e.g., *kuhalec), 30 non-words (e.g., *dovina) and 30 existing Slovenian deverbal nouns for masculine agents (e.g., plavalec). For each of the stimuli, the participants had to provide a "yes" or "no" answer, responding to the question, "In your opinion, is this word part of Slovenian vocabulary?" If their answer was "yes," they were also asked to provide the meaning of this word.

The pool of 30 items per category ( 22 for thematic violations) was chosen according to each word's frequency tested in the Corpus of the Slovenian language FidaPlus

${ }^{12} \mathrm{~A}$ reviewer pointed out that the mere fact that we are using one of the most frequent and productive affix in deriving a masculine agent contributes to a higher degree of acceptability of the derived words. While we agree that the frequency and productive nature of this affix contribute to the degree of certainty with which the speakers judge the words as acceptable or non-acceptable, it has to be pointed out that frequency and productivity do not seem to play a role when it comes to the degree of acceptability, given a massive rejection of words with aspectual and categorial violations. 
(Korpus slovenskega jezika FidaPLUS).$^{13}$ We made sure that the arithmetic mean of the frequencies (i.e., number of appearances within FidaPlus) was similar in all the word groups. Since pseudo-words are not part of the vocabulary of a certain language, we could not test them directly by inserting them into the corpus. Therefore, we used a closely related lexicalized word on which the pseudo-word was based. We used the infinitive form of verbs to check out the stimuli belonging to the category of pseudo-words with thematic violations (e.g., for a pseudo word *umiralec 'die-er', we looked up an infinitive form of a verb umirati 'to die'). The same verb form was used also to check out the stimuli belonging to the category of possible pseudo-words (e.g., for *risalec 'draw-er' we looked up risati 'to draw'). But for the other two categories of violations we used nouns in the nominative case. For the stimuli belonging to aspectual violations such as *preplavalec, we looked up the noun plavalec 'swimmer', and for the stimuli with categorial violations such as *travilec we looked up the noun trava 'grass'. Finally, the frequency of non-words such as *lastje could not be checked, since these words are non-existent and do not have a lexicalized word on which they could be based. The samples of the stimuli, their characteristics and mean frequencies and roles can be found in Table 1:

\begin{tabular}{|l|l|l|l|}
\hline Type of stimulus & Characteristics & Example & Mean frequency \\
\hline $\begin{array}{l}\text { Pseudo-words with } \\
\text { thematic violations: } \\
\text { Pseudo-Them }\end{array}$ & $\begin{array}{l}\text { violations of the basic } \\
\text { relationships concern- } \\
\text { ing thematic roles }\end{array}$ & $\begin{array}{l}\text { *počivalec ('rest-er') } \\
\text { *rumenelec ('become- } \\
\text { yellow-er') }\end{array}$ & 2290.5 \\
\hline $\begin{array}{l}\text { Pseudo-words with } \\
\text { categorial violations: } \\
\text { Pseudo-Cat }\end{array}$ & $\begin{array}{l}\text { lexical category of the } \\
\text { root is inappropriate }\end{array}$ & $\begin{array}{l}\text { *črkilec ('letter-er') } \\
\text { *travilec ('grass-er') }\end{array}$ & 2366.53 \\
\hline $\begin{array}{l}\text { Pseudo-words with } \\
\text { aspectual violations: } \\
\text { Pseudo-Asp }\end{array}$ & $\begin{array}{l}\text { violation of word-for- } \\
\text { mation rules relating to } \\
\text { verbal aspect }\end{array}$ & $\begin{array}{l}\text { *preplavalec (from pre- } \\
\text { plavati 'to swim-pf') } \\
\text { *umorilec (from } \\
\text { umoriti 'to murder-pf') }\end{array}$ & 2090.27 \\
\hline $\begin{array}{l}\text { Possible Pseudo- } \\
\text { Words: } \\
\text { Pseudo-Poss }\end{array}$ & $\begin{array}{l}\text { do not violate any of } \\
\text { the above rules, but do } \\
\text { not exist in Slovenian } \\
\text { vocabulary }\end{array}$ & $\begin{array}{l}\text { *risalec (risar ex- } \\
\text { ists for 'drawer') } \\
\text { *kuhalec ( } k \text { kuhar } \text { exists } \\
\text { for 'cook') }\end{array}$ & 2440.93 \\
\hline $\begin{array}{l}\text { Words for masculine } \\
\text { agents: } \\
\text { W-X }\end{array}$ & $\begin{array}{l}\text { words which are part of } \\
\text { Slovenian vocabulary }\end{array}$ & $\begin{array}{l}\text { plavalec ('swimmer') } \\
\text { občudovalec } \\
\text { ('admirer') }\end{array}$ & 2698.77 \\
\hline $\begin{array}{l}\text { Non-Words: } \\
\text { Non-W }\end{array}$ & $\begin{array}{l}\text { roots are nonexistent in } \\
\text { Slovenian }\end{array}$ & $\begin{array}{l}\text { *dovina } \\
\text { *lastje }\end{array}$ & 0 \\
\hline
\end{tabular}

Table 1: Samples of stimuli used in the study

${ }^{13}$ The number of stimuli containing thematic violations is lower than the number for other categories because we could provide only 22 verbs in which the frequencies matched the frequencies of the rest of the stimuli. 


\subsection{Analysis and results}

The acceptance rates indicate how many times the participants decided the presented word was a real Slovenian word. The results are presented in Table 2:

\begin{tabular}{|c|c|c|c|c|c|c|}
\hline & W-X & Pseudo-Poss & Pseudo-Asp & Pseudo-Them & Pseudo-Cat & Non-W \\
\hline AR & $98.40 \%$ & $5.20 \%$ & $2.10 \%$ & $1.90 \%$ & $0.86 \%$ & $0.50 \%$ \\
\hline
\end{tabular}

Table 2: The acceptance rates (AR) for six categories of stimuli

The acceptance rates reveal that the participants accepted only existing Slovenian deverbal nouns for masculine agents (e.g., plavalec), and rejected practically all the pseudo-words with violations. The only exception was the category of possible pseudo-words (e.g., *risalec) with no word-formation violation. These had a slightly higher acceptance rate, and this difference was statistically significant (See Table 3, where the significant occurrences are highlighted in gray). We carried out a Paired Samples t-test which enabled us to compare the results of the participants between the six different categories of stimuli and, thus, to compare the sensitivity of the participants to different word-formation rules. When comparing the results, we were comparing the correct answers, i.e., "no" for all the pseudo-words (pseudo-words with thematic, aspectual and categorial violations, possible pseudo-words) and non-words, and "yes" for the existing words. The results were as follows in Table 3:

\begin{tabular}{|l|l|l|l|l|}
\hline Compared categories & SD & Df & t-scores & p value \\
\hline Non-W vs Pseudo-Poss & 1.531 & 19 & -3.943 & 0.001 \\
\hline Non-W vs Pseudo-Asp & 1.429 & 19 & -1.252 & 0.226 \\
\hline Non-W vs Pseudo-Them & 0.786 & 19 & -1.422 & 0.171 \\
\hline Non-W vs Pseudo-Cat & 0.788 & 19 & -.567 & 0.577 \\
\hline Non-W vs W-X & 0.616 & 19 & -1.453 & 0.163 \\
\hline Pseudo-Poss vs Pseudo-Asp & 1.504 & 19 & -2.826 & 0.011 \\
\hline Pseudo-Poss vs Pseudo-Them & 1.483 & 19 & 3.317 & 0.004 \\
\hline Pseudo-Poss vs Pseudo-Cat & 1.251 & 19 & 4.467 & 0.000 \\
\hline Pseudo-Poss vs W-X & 1.785 & 19 & 2.881 & 0.01 \\
\hline Pseudo-Asp vs Pseudo-Them & 1.461 & 19 & .459 & 0.651 \\
\hline Pseudo-Asp vs Pseudo- Cat & 1.593 & 19 & .842 & 0.41 \\
\hline Pseudo-Asp vs W-X & 1.508 & 19 & .593 & 0.56 \\
\hline Pseudo-Them vs Pseudo- Cat & 1.089 & 19 & -.616 & 0.545 \\
\hline Pseudo-Them vs W-X & 1.508 & 19 & .237 & 0.815 \\
\hline Pseudo- Cat vs W-X & 1.119 & 19 & -.400 & 0.694 \\
\hline
\end{tabular}

Table 3: Comparison (Paired Samples t-test) of six presented categories of stimuli 


\subsection{Interpretation}

The presented results indicate that participants made a clear line between pseudo-words that violate the word-formation rules of Slovenian (aspectual, categorial, and thematic violations) and words that do not (existing Slovenian words for masculine agents and possible pseudo-words). Words with aspectual, categorial or thematic violations were treated by speakers as being pure non-words. This is made clear by the lack of any statistically significant difference between the acceptance rates of pseudo words with violations and non-words (see Table 3). This is also an indication that for native speakers of Slovenian all the violated rules have the same significance (rejecting Hypothesis 1). Although the acceptance rate for possible pseudo-words is still very low, there is a significant difference between this group of words, which do not violate any word-formation rules, and between pseudo-words with violations (see Table 3), even though both types are non-attested (supporting Hypothesis 2). To sum up, the results indicate that the participants do not differentiate at all among pseudo-words with different types of violations, thus revealing that all the violated word-formation rules have the same significance for them. It appears that word-formation rules within the Slovenian language all have the same weight for native speakers and that we do not find "strong" and "weak" constraints (rules), as is the case in Modern Greek (Manouilidou 2007). ${ }^{14}$

\section{Conclusion}

The goal of this research was to investigate the status of various word-formation rules by examining speakers' perceptions of pseudo-words that violate these rules, basing the experiment on one carried out for Modern Greek (Manouilidou 2007). The study, which was limited to the agentive deverbal nominalization and included 20 native speakers of Slovenian, revealed that native speakers of Slovenian make a clear line between pseudo-words that violate word-formation rules of Slovenian and words that do not, but that they do not differentiate between the pseudo-words with different types of violations as they equally reject all pseudo-words with various kinds of violations (categorial, thematic, aspectual). This is the first study of its kind conducted on native speakers of Slovenian, and it reveals important information about the status of different

${ }^{14}$ We leave the explanation as to the source of the difference between these two groups of speakers for future research; at this point we can only speculate about two possible explanations. While in Greek there are temporal and quantitative differences in the processing of various constraints, in Slovenian the distinction between constraints is not robust. Although both languages have strict morphological systems, Greek, on the one hand, demonstrates a higher permissiveness of pseudo-words, suggesting that constraints are well-defined, distinct from one another and treated as such in this language. Slovenian, in contrast, shows lower permissiveness (all pseudo-words are rejected) which could be the result of two facts. Either constraints are not well-defined, and speakers cannot differentiate between them, or there is a different attitude towards pseudo-words from the point of view of native speakers. This issue requires further investigation. Finally, in order to be able to compare the two languages a chronometric, on-line task for Slovenian is necessary. 
word-formation rules in Slovenian as well as information as to the differences in acceptance rates between native speakers of different languages. The findings of the present study also set a baseline for using similar linguistic tasks as tools for testing Slovenian native speakers whose mental lexicons are impaired, either as a result of cognitive decline (i.e., in Alzheimer's disease patients) or as a result of a focal brain-damage (i.e., in stroke patients) in order to reveal the extent to which their knowledge of Slovenian word-formation rules and vocabulary is degraded. ${ }^{15}$ The study also provided normative data for Slovenian, which are currently being used for testing the degree of lexical impairment in speakers with impaired lexicons (see Manouilidou et al, in prep).

\section{References}

Alexiadou, Artemis and Florian Schäfer. 2008. Instrumental -er Nominals Revisited. In OnlineProceedings of WCCFL XXVII (Poster Session) 10-19, ed. by Kevin Ryan. UCLA Working Papers in Linguistics.

Barker, Chris. 1998. Episodic -ee in English: A Thematic Role Constraint on New Word Formation. Language 74: 695-727.

Bauer, Laurie. 2003. Introducing Linguistic Morphology. Edinburgh: Edinburgh University Press.

Embick, David. 2007. Blocking Effects and Analytic/Synthetic Alternations. Natural Language \& Linguistic Theory 25: 1-37.

Embick, David. 2010. Localism versus Globalism in Morphology and Phonology. Cambridge, MA: MIT Press.

Fabb, Nigel. 1988. English Suffixation Is Constrained Only by Selectional Restrictions. Natural Language \& Linguistic Theory 6: 527-539.

Giegerich, Heinz J. 1999. Lexical Strata in English: Morphological Causes, Phonological Effects. Cambridge: Cambridge University Press.

Halle, Morris and Alec Marantz. 1993. Distributed Morphology and the Pieces of Inflection. The View from Building 20: Essays in Linguistics in Honor of Sylvain Bromberger, ed. by Kenneth Hale and S. Jay Keyser. Cambridge, MA: MIT Press, 111-76.

Korpus slovenskega jezika FidaPLUS. Retrieved: 30.11.2012, from http://www.fidaplus.net/.

Manouilidou, Christina. 2007. Thematic Constraints in Deverbal Word Formation: Psycholinguistic Evidence from the Processing of Pseudo Words. In Proceedings of the 7th International Conference on Greek Linguistics. University of York, UK.

Manouilidou, Christina, Barbara Dolenc, Tatjana Marvin, Katarina Marjanovič and Zvezdan Pirtošek. in prep. Processing Pseudo-words in Mild Cognitive Impairment: Off-line and On-line Evidence from Slovenian. Ms. University of Ljubljana.

Marantz, Alec. 2001. Words. Ms. MIT.

Marjanovič, Katarina. 2013. Processing of Words and Pseudo-words in Patients with Dementia. MA thesis. University of Ljubljana.

Marvin, Tatjana. 2002. Topics in the Stress and Syntax of Words. Cambridge, MA: MIT Working Papers in Linguistics.

O'Grady, William, Michael Dobrovolsky, and Mark Aronoff. 1997. Contemporary Linguistics: An Introduction. New York, NY: St. Martin's Press.

Plag, Ingo. 1996. Selectional Restrictions in English Suffixation Revisited. A Reply to Fabb (1988). Linguistics 34: 769-798.

\footnotetext{
${ }^{15}$ A case study of a speaker with Alzheimer's disease is found in Marjanovič 2013.
} 
Plag, Ingo. 1999. Morphological Productivity. Structural Constraints in English Derivation. Berlin/New York: Mouton de Gruyter.

Plag, Ingo. 2003. Word-formation in English. Cambridge: Cambridge University Press.

Rappaport Hovav, Malka, and Beth Levin. 1992. -er Nominals: Implications for a Theory of Argument Structure. Syntax and Semantics 26: 127-153.

Spencer, Andrew. 1991. Morphological Theory: An Introduction to Word Structure in Generative Grammar. Oxford: Blackwell.

Stramljič Breznik, Irena. 1994/95. Specializiranost obrazil za izpeljanke s pomenom vršilca dejanja, nosilca lastnosti ali stanja in opravkarja. Jezik in slovstvo 40: 285-291.

Stramljič Breznik, Irena. 1999. Prispevki iz slovenskega besedoslovja. Maribor: Zora. Toporišič, Jože. 2000. Slovenska slovnica. Maribor: Založba Obzorja.

Vidovič-Muha, Ada. 2012. Slovensko skladenjsko besedotvorje. Ljubljana: Znanstvena založba Filozofske fakultete.

Appendix: List of words and pseudo-words presented to the participants of the experiment.

\begin{tabular}{lll}
$\begin{array}{l}\text { Pseudo-words } \\
\text { with thematic } \\
\text { violations }\end{array}$ & $\begin{array}{l}\text { Pseudo-words } \\
\text { with categorial } \\
\text { violations }\end{array}$ & $\begin{array}{l}\text { Pseudo-words } \\
\text { with aspectual } \\
\text { violations }\end{array}$ \\
\hline bingljalec & antenilec & nahranilec \\
bolelec & balonilec & ocenilec \\
cvetelec & buldožerilec & oskrunilec \\
dihalec & čokoladilec & počistilec \\
gostovalec & črkilec & pogasilec \\
jokalec & dlakilec & pokadilec \\
kolcalec & gromilec & posadilec \\
krvavelec & gumilec & posejalec \\
ležalec & iglilec & posekalec \\
ljubilec & jadrilec & pozdravilec \\
oskrbelec & kremilec & prebralec \\
počivalec & medaljilec & prejadralec \\
rumenelec & mizilec & prekršilec \\
sedelec & nogavilec & preletalec \\
sovražilec & nohtilec & preplavalec \\
stalec & odejilec & preplesalec \\
trpelec & orehilec & preplezalec \\
umiralec & ptičilec & preposlušalec \\
venelec & ravnilec & prepotovalec \\
viselec & rjuhilec & preskakalec \\
zorelec & rožilec & presnemalec \\
živelec & srajčilec & sporočevalec \\
& strehilec & ubranilec \\
& škatlilec & ukrotilec \\
tabletilec & ulovilec \\
& &
\end{tabular}




$\begin{array}{ll}\text { tablilec } & \text { umorilec } \\ \text { tortilec } & \text { ustrelec } \\ \text { trakilec } & \text { zaprosilec } \\ \text { travilec } & \text { zasadilec } \\ \text { vazilec } & \text { zlomilec }\end{array}$

\begin{tabular}{lll} 
Possible & Words for & \\
Pseudo Words & masculine agents & Non-Words \\
\hline anketiralec & bralec & antobiotik \\
bahalec & branilec & avtolibil \\
balinalec & lovilec & bostelja \\
boksalec & pletilec & buldomer \\
čuvalec & kadilec & čokovada \\
čvekalec & jadralec & dalžina \\
garalec & plavalec & dosenček \\
godrnjalec & jahalec & dovina \\
jodlalec & plesalec & emastika \\
klepalec & dajalec & fekulteta \\
klicalec & morilec & gogovje \\
kričalec & gasilec & hokavica \\
krmilec & jemalec & hučitelj \\
kuhalec & darovalec & intervet \\
nastopalec & plezalec & kamira \\
pekalec & pihalec & kapuščina \\
pisalec & drsalec & lemsikon \\
pleskalec & opazovalec & ljabezen \\
potapljalec & krotilec & memljevid \\
pretepalec & metalec & minčnik \\
računalec & cepilec & molezen \\
risalec & iskalec & nagramenec \\
sankalec & prosilec & nastovač \\
slikalec & reševalec & pemenka \\
smučalec & skakalec & sohraštvo \\
tekalec & snemalec & stomica \\
tiskalec & storilec & temefon \\
tolmačilec & tožilec & tobleta \\
vozalec & zbiralec & trivališče \\
zabavljalec & zdravilec & unimerza \\
& & \\
& &
\end{tabular}

Prispelo marca 2013, sprejeto aprila 2013

Received March 2013, accepted April 2013 
Besedotvorna pravila pri slovenskih izglagolskih izpeljankah za vršilca dejanja: psiholingvistična študija na osnovi psevdobesed

$\mathrm{V}$ članku se ukvarjamo z raziskavo pomena različnih besedotvornih pravil v povezavi z izpeljavo slovenskih samostalnikov, ki označujejo vršilca dejanja, tako da ugotavljamo, kako govorci sprejemajo psevdobesede, ki ta različna besedotvorna pravila kršijo. Poskus temelji na podobnem poskusu za moderno grščino v Manouilidou (2007), ki je pokazal, da rojeni govorci moderne grščine ločijo med besedotvornimi pravili tako, da nekatera lažje kršijo kot druga, in sicer da pri izpeljavi lažje kršijo pravila, ki zadevajo udeležensko strukturo besede, kot tista, ki se nanašajo na besednovrstne omejitve pri izpeljavi besede. Naš cilj je bil ugotoviti, če se govorci slovenščine obnašajo podobno pri primerljivih besedotvornih postopkih (tj. če razlikujejo med udeleženskimi in besednovrstnimi kršitvami v izpeljankah za vršilca dejanja), ter preveriti še dodatno besedotvorno pravilo, ki se nanaša na glagolski vid (tj. vidske kršitve pri izpeljankah za vršilca dejanja).

Raziskava je potekala v obliki poskusa, kjer smo udeležencem, 20 rojenim govorcem slovenščine, pokazali seznam psevdobesed z različnimi kršitvami ter jih prosili, da za vsako besedo povedo, ali je po njihovem mnenju del slovenskega besedišča. Rezultati pokažejo, da rojeni govorci slovenščine vse psevdobesede $\mathrm{z}$ besedotvornimi kršitvami obravnavajo enako; v nasprotju z grškimi govorci enako odločno zavračajo besede tako z udeleženskimi kot besednovrstnimi kršitvami, tako kot tudi zavračajo besede s kršitvami glagolskega vida. V poskusu smo testirali še četrto skupino psevdobesed, t.i. »možne psevdobesede«, ki so definirane kot psevdobesede brez besedotvornih kršitev, ki pa kljub temu niso del slovenskega besedišča, saj imamo namesto njih v rabi že leksikalizirane druge besede $\mathrm{z}$ istim pomenom. Študija pokaže, da med možnimi psevdobesedami in psevdobesedami s kršitvami obstaja statistična razlika v sprejemljivosti v korist možnih psevdobesed, četudi je procent sprejemljivosti možnih psevdobesed še vedno relativno nizek v primerjavi s procentom sprejemljivosti obstoječih besed brez kršitev.

To je prva tovrstna študija, ki je bila izvedena na rojenih govorcih slovenskega jezika. Pomembna je kot vir podatkov o statusu različnih besedotvornih pravil pri slovenskih govorcih, hkrati pa nam služi za primerjavo statusa pravil pri govorcih različnih jezikov. Izsledki študije so tudi osnova za uporabo podobnih jezikovnih nalog pri testiranju govorcev slovenskega jezika, pri katerih je leksikon prizadet zaradi upada splošnih kognitivnih sposobnosti (pri npr. bolnikih z alzheimerjevo demenco) ali zaradi možganskih poškodb (pri bolnikih s kapjo), saj lahko preko rezultatov tovrstnih poskusov določimo, do kakšne mere je prizadeto bolnikovo znanje slovenskih besedotvornih pravil in besedišča. 


\section{Word-Formation Rules in Slovenian Agentive Deverbal Nominalization: A Psycholinguistic Study Based on Pseudo-Words}

The goal of this research is to investigate the status of various word-formation rules in deverbal agentive nominalization in Slovenian by examining speakers' perception of pseudo-words that violate these rules. The study is based on a similar study conducted for Modern Greek in Manouilidou (2007), which showed that native speakers of Modern Greek differentiate among word-formation rules in the sense that some rules are more readily violated than others, more specifically, that rules pertaining to the thematic structure are more easily violated than those pertaining to the category of the constituent parts. Our goal was to establish whether native speakers of Slovenian show a similar behavior, testing the word-formation rules that were tested in Modern Greek for the same construction (i.e., thematic and categorial violations in the agentive nominalization) as well as an additional word-formation rule (i.e., aspectual violations in the agentive nominalization), the status of which had yet to be established.

The study was carried out as an off-line experiment, where pseudo-words with different types of violations were presented to 20 native speakers of Slovenian who had to decide for each word whether or not it was part of Slovenian vocabulary. The results reveal that, contrary to the findings for Modern Greek, thematic rules do not have a different status from categorial rules, and that aspectual rules have the same status in speakers' perception as the thematic and categorial ones. In our experiment we created also a fourth type of pseudo-words, the so-called possible pseudo-words, which are words that do not violate any word-formation rule of Slovenian but, nevertheless, do not exist in Slovenian vocabulary since there are other lexicalized words conveying the meaning of a masculine agent in the language. The study reveals that although the acceptance rate for possible pseudo-words is still very low, there is a significant difference between this group of words, which do not violate any word-formation rules, and between pseudo-words with categorial, thematic or aspectual violations.

This is the first study of its kind conducted on native speakers of Slovenian, and it reveals important information about the status of different word-formation rules among Slovenian speakers as well as information as to the differences in acceptance rates between native speakers of different languages. The findings of the present study also set a baseline for using similar linguistic tasks as tools for testing Slovenian native speakers whose mental lexicons are impaired, either as a result of cognitive decline (i.e., in Alzheimer's disease patients) or as a result of a focal braindamage (i.e., in stroke patients) in order to reveal the extent to which their knowledge of Slovenian word-formation rules and vocabulary is degraded. 
